\title{
Empirical Verification of the Existence and Functioning of Internal Controls in the Preparation of a Consolidated Property Balance Sheet for the State and Municipalities in Slovenia
}

\author{
UDK: 35:336.146(497.4) \\ Jasna Ida Zafred \\ Urad RS za nadzor proračuna \\ jasna.zafred@gmail.com
}

\section{ABSTRACT}

The consolidation process, where a group of enterprises is presented as a single one, is prescribed by international accounting standards, and in accordance with them it has been taken over by Slovenian accounting standards and International Public Sector Accounting Standards. It may be conducted after prior preparation of basic financial statements of the controlling and the controlled enterprise. From the professional directives derives one of the demands that between consolidated standings there must not be any so-called "quasi-differences" due to unregulated accounting.

In spite of the fact that Slovenian subjects of the public sector do not prepare financial statements in a way as determined by the standards, consolidation is being carried out, but for certain data of the balance sheets and based on a special regulation. This regulation allows the appearance of differences between the budgets users what influences the standing of the general state fund.

In the research, by the method of random sampling by the use of an opinion poll according to the components of the COSO model, we empirically verified the effectiveness of the internal controlling system in the preparation of original documents of the balance sheets in the Slovenian public sector. We found out that formally differences are allowed, even quasi-differences, due

Zafred, J. I. (2011). Empirical Verification of the Existence and Functioning of Internal Controls in the Preparation of a Consolidated Property Balance Sheet for the State and Municipalities in Slovenia. Uprava IX(4), 73-95. 
Empirical Verification of the Existence and Functioning of Internal

Controls in the Preparation of a Consolidated Property Balance Sheet

for the State and Municipalities in Slovenia

to which reliability of a consolidation financial statement is questionable. Verification of the component of the controlling environment has shown for example that legal limitation periods for the confirmation of open positions are determined too early, and the proceedings are not agreed upon exactly enough when there is an imbalance between receivables and liabilities in the consolidation. In situations of short-term receivables and liabilities towards budget users in 31.12., there are standings that may lead to the risk of appearance of differences in the consolidation and for a string of accounts we found in the component of the controlling activity that budget users did not even the standings successfully or did not even balance the standings in 31.12., due to what differences appeared. This was the cause that measures were determined by accounting offices for the avoiding of an appearance of differences. The question of the component of information and communication was answered by accountants who wish they had more education, and the superiors who could use the information from financial statements better for their decision-making. Their software is still not safe enough, as in some cases the database of financial data is accessed. The results in the component of following showed that in several places audits of the procedure of preparation of property balance sheets were not performed.

Keywords: consolidation, COSO model, quasi-differences, random sampling, opinion poll

JEL: $H 83$

\section{Introduction}

Due to the growing difference between the declarative promises of policy and the actual conducting of public services financed from tax payers' money, the public sector of the developed OECD countries started to focus on the private sector in the last decades of the 20th century with regards to the development of quality criteria, economic effectiveness, and the effective conducting and transparency of financing public services. The reforms brought a lot of practices otherwise established in the private sector to the public sector.

The central part of the reform of the public sector was also represented by the change of the accounting system. All states carrying out the reform of the public sector also conducted the transition from accounting based on cash flow to accounting based on business events.

The International Public Sector Accounting Standards Board at the International Federation of Accountants - IFAC Board - developed high 
quality accounting standards for the public sector (International Public Sector Accounting Standards, [IPSAS]), especially for complete and qualitative accounting reports. By IPSAS, the consistency and comparability of accounting information in different legal systems are reached, and therefore governments and national standard-setters are encouraged to cooperate in the development of these standards with their proposals.

The published IPSAS are prepared for accounting-based cash flow, as well as for accounting based on business events. It is possible to prepare basic financial statements and with them to make a complete consolidation, if based on the latter. The basic characteristics of a consolidated financial statement excluded mutual business receivables and business liabilities, and mutual income and spending. Provided that there is regulated accounting, these values are the same for the creditor and debtor. There are real ones as consequences of the different ways of validating accounting positions that were excluded by us due to unified provisions for public sector subjects in our research. If the differences are unreal, they are the consequence of a deficiency in the execution of the accounting function.

The accounting system of public sector subjects is modified in Slovenia, as it contains the characteristic proceedings of one or another accounting system. In spite of this, from certain data of the public law subjects' balance sheets a consolidated financial statement of the state is being prepared, the consolidated property balance sheet of the state and the municipalities. The provision allows for differences in the consolidated standings of accounting positions changing the book standing of the state business fund on the last level of the consolidation process.

In the contribution, we focused on the nature of allowed mistakes that should be discovered and repaired by an internal controlling system in due time. We used the COSO - model (Committee of Sponsoring Organisations of the Treadway Commission's integrated framework for internal control) and by statistical method of random sampling by the use of an opinion poll, we studied individual activities in the viewing of business events in original documents, which are the basis for the preparation of a consolidated property balance sheet of the state and the municipalities. 
Empirical Verification of the Existence and Functioning of Internal

Controls in the Preparation of a Consolidated Property Balance Sheet

for the State and Municipalities in Slovenia

\section{Theoretical and legal bases for the preparation of a consolidated property balance sheet of the state and municipalities}

\subsection{Consolidated financial statements in the private sector}

Slovenian Accounting Standards (SAS) being based on international accounting standards (in continuation: IAS) determine in their introduction (2006, p. 15) that a group is represented in consolidated financial statements, as if it was one individual enterprise. They may be prepared in the conditions of accounting based on business events and composed of individual basic financial statements of consolidated enterprises with according consolidation corrections. The group is represented by:

- a controlling enterprise;

- controlled enterprises due to the share of the capital;

- controlled enterprises due to the controlling influence for other reasons,

and the proceedings are called "complete consolidation" by SAS.

At the introduction of a complete consolidation of individual financial statements, we have to provide:

- the use of unified accounting directives for similar business events;

- as a rule the same representation of positions in the financial statements;

- the composition of financial statements for the business year usually ending on the same day;

- a method of exchange from a foreign currency.

By realisation of demanded guarantees, individual real and honest financial statements should be completely consolidated into consolidated financial statements without mistakes. But, mistakes very probably exist as value differences. In literature, there are differences appearing in a consolidation of receivables and liabilities separated in two groups (Vrankar, 1995, p. 97-98):

1. Quasi-differences are a consequence of mistakes. They derive from false booking, calculations of business events that are not harmonised in time, or booked in different times. "Quasidifferences can be avoided by a good organisation and a 
harmonisation of receivables and liabilities between enterprises in a group."

2. Real differences are no consequence of mistakes, but of the use of different ways of validation of assets and liabilities that have to be respected in the preparation of financial statements, or for example the use of different ratings of currencies on the day of booking and on 31.12.

If there are mistakes, then they exist in the individual financial statements, as consolidation is usually carried out by software, and the accounting positions of consolidated financial statements are not subject to booking.

\subsection{Basic and consolidated financial statements in the public sector}

Also IPSAS are based on IAS. They preserve accounting procedures and the original text of IAS wherever this is founded, but at the same time they develop any field not contained in IAS. They represent professional international solutions for the preparation of financial statements of public law subjects for two basic ways of accounting:

- based on cash flow;

- based on business events.

While preparation of financial statements based on cash flow is defined in one single standard that was at last published in the IPSAS Handbook (Handbook of International Public Sector Accounting Pronouncements, 2011, p. 1450-1574), accounting based on business events is based on 31 IPSAS. IPSAS 1 - Presentation of Financial Statements. Complete financial statements, according to IPSAS 1 (Handbook of International Public Sector Accounting Pronouncements, 2007, p. 36-37), encompass:

1. Statement of financial position;

2. Statement of financial performance;

3. Statement of changes in net assets/equity;

4. Cash flow statement;

5. Comparison of budget and actual amounts as a divided additional financial statement or as a column in the financial statements, when a public law subject publishes its valid budget; 
Empirical Verification of the Existence and Functioning of Internal

Controls in the Preparation of a Consolidated Property Balance Sheet

for the State and Municipalities in Slovenia

6. Notes, comprising a summary of significant accounting policies and other explanatory notes.

Subjects in public sector conduct, accrual accounting, and preparing consolidated financial statements use IPSAS 6 - Consolidated and Separate Financial Statements. The standard provides procedures that have to be conducted in the consolidation (Handbook of International Public Sector Accounting Pronouncements, 2007, p. 198-200), and are technically the same as in the preparation of consolidated financial statements in the private sector.

\subsection{Basic and consolidated financial statements in the slovenian public sector}

The accounting of subjects in the public sector is modified in Slovene. It contains elements of cash accounting and accrual accounting. The legal basis for the preparation of financial statements of public law subjects in Slovenia are the Act on Public Finances (APF), the Act on Accounting (AA) and executive acts adopted based on them. The AA provides in article 21 that an annual report is composed of:

- a balance sheet;

- profit and loss account;

- explanations to the statements;

- the business report.

In the Slovenian public sector, three sorts of consolidated financial statements are prepared:

- The Ministry of Finance prepares a »consolidated global profit and loss account of public financing" encompassing the "consolidated flow of four treasuries of public financing, "' ${ }^{1}$ among which the transfer flows are excepted, and their preparation does not have an expressive basis;

- Based on the European legal order, ${ }^{2}$ the Statistical Office of the RS is preparing twice per year a report on the state deficit and debts,

\footnotetext{
1 The four treasuries of public financing are: state budget, treasury of pension and invalidity insurance, treasury of obligatory health insurance and budgets of municipalities.

2 It is based on the methodology of ESR 95 Manual on Government Deficit and Debt and other European legal sources, Regulation by the Council of Europe no. 3605/1993, Regulation by the Council of Europe no. 475/2000, Regulation by the Council of Europe
} 
where sall incomes and spending of all institutional units of the state sector are encompassed, even those that are not included in the consolidated global profit and loss account of public financing or are encompassed there only partly, respectively« (Report on the State Deficit and Debts, 2010, p. 20);

- Article 93 APF and article 29 AA determine the preparation of a consolidated financial statement of the state and the municipalities also named an act of the state, and a special provision is adopted for the preparation of this - the standing orders on the preparation of a consolidated property balance sheet of the state and the municipalities.

Formally, the standing orders on the preparation of a consolidated property balance sheet of the state and the municipalities only prescribes a consolidation of certain data from the balance sheets of subjects ${ }^{3}$ in the public sector including in subsectors of the central state, local government, and social funds. In the proceedings, formally differences are allowed. They appear in the consolidation of balance positions between subjects in the public sector within an individual subsector that influence the booked standing of the general treasury of the state on the last level.

\subsection{Relevance of financial statements in private and public sector}

Consolidated financial statements, as much as basic ones, are prepared for general purpose, namely for users who cannot demand accounting information for their special needs. Basic financial statements for a group of enterprises or public law subjects, respectively, and the consolidated financial statements conducted from these, are meant for internal reporting, management, and other decision-making levels in the private, as well as in the public sector. They are also meant for external users, investors, creditors, and other business partners who need information from (consolidated) balance sheets for their decision-making. The influence of various data from a balance sheet on decisions of external users in the private sector was researched by Bessete, 2003;

no. 2103/2005 and Regulation by the European Commission no. 351/2002 (Report on the Government Deficit and Debt, 2009).

3 Besides the demands and obligations also passive and active reservations, unpaid income and spending and amounts of investments in property with a purpose in the amounts of the referring funds. 
Users of basic financial statements of subjects in the public sector representing subsectors of a central state, local governments, and social funds after consolidation are citizens, tax payers, voters, politicians, members of boards of trustees, working bodies of state departments, ministries, and organizations in their composition, chambers and various associations, and other subjects in the public sector like agencies, committees, and users with an interest. The calculation of the state deficit and debts mainly lies in the domain of state statistics and macroeconomic analyses, and in the environment of accounting based on business events, though it is also possible in the function of public accounting. At the change of the millennium, this novelty in the public sector was researched by Matheson, 2002; Hepworth, 2002; Pallot, 2002; Hodque \& Moll, 2001; Allen \& Chan, 2002; Vašiček \& Vašiček, 2000, and later by Broadbent \& Guthrie, 2008; Kelly \& Wanna, 2004; Wilks, 2007; Papenfuß \& Schaefer, 2009; Benito, Brusca \& Montesinos, 2009; Pérez \& López-Hernández.

Consolidated financial statements in the Slovenian private sector was brought closer to us by M. Vrankar (2009), despite the fact that we can only read about state consolidated financial statements from official reports by the Ministry of Finance and the Audit Court of the Republic of Slovenia.

\subsection{Basic thesis of the research}

Consolidation procedure after IAS and IPSAS can follow only workedout, basic financial statements prepared under conditions of accrual accounting. In the Slovenian public sector, we have a modified way of accounting. Therefore, it is not probable that proceedings of consolidation of financial statements in different systems could be comparable. But, in spite of the prescribed procedure of consolidated property balance sheet of the state and the municipalities in Slovenia, we were of the opinion that the provision cannot change the principles of a regulated bookkeeping being realised within a consolidation procedure for the same business in the same value by excluding booked receivables in one, and the liabilities in another subject in the public sector. Based on one of the demands of the consolidation procedure that established standings, business, income, and spending among subjects in the public 
sector within the group are excluded as a whole, we put the question at the beginning, why in the consolidated standing are there quasidifferences, or how internal controls work in the consolidation process of balance positions within the property balance sheet of the state and the municipalities, respectively. Our thesis is that consolidated standings for which there is no prior controlling system or it has not discovered identical balance positions, do not provide for a credible consolidated financial statement.

We used random sampling in the form of an opinion poll to empirically check the components of the COSO model, whether the existing system of internal controls in the process of preparation of a consolidated property balance sheet of the state and the municipalities in Slovenia discovers identical balance positions that condition the credibility of the consolidation process. We statistically processed responses to the questions of a closed type in sample (n), and with a certain degree of risk and reliability of the assessment, we interpreted this for the entire population ( $P$ ). Then, with these closed questions, we founded the statistical result for a certain response using opinions.

\section{Empirical verification of the credibility of the proceedings of preparation of a consolidated property balance sheet of the state and municipalities ${ }^{4}$}

\subsection{Definition of the population}

The target population of the research was represented by subjects in the public sector from the attachment to the standing orders on the determination of immediate and mediate users of the state and municipal budgets, updated on 31.12.2009 and published on the internet page of the Public Payment Office of the Republic of Slovenia (http://www.ujp. gov.si/dokumenti/dokument.asp?id=122). It included 2,829 public subjects. The sample frame of the poll population was represented in this research by all subjects in the public sector from the published list by the Public Payment Office of the Republic of Slovenia, from which all local communities, town quarters, and administrative units were excluded,

4 More detailed about this, see: Zafred, J. I. (2010): Prevzem mednarodnih računovodskih standardov za javni sektor v računovodske izkaze oseb javnega prava - primer Slovenije (doktorska disertacija). Ljubljana: Ekonomska fakulteta (Faculty of Economics). 
in total 950 subjects or $34 \%$ of the target population. Most of the identified excluded elements could not be located in another way, if we declare the location of the element in the target population of the respective research as accessibility of the internet address of the subjects in the public sector. An unpublished internet address of a subject is therefore an inappropriate, empty element that did not belong to the target population (Kalton \& Vehovar, 2001, p. 72). Therefore, these elements were not considered. An important consequence of inappropriate elements is that the size of the sample is diminished. Therefore, they have to be predicted and their size has to be roughly validated and then, the sample has to be increased accordingly. After determination of the sample frame, the polled population of the research contained 1,879 elements $(N=1879)$.

\subsection{Opinion poll}

The decision to use an opinion poll, and research of the existence and functioning of internal controls in the process of preparation of a consolidated property balance sheet of the state and the municipalities, was based mainly on these starting-points:

1. Property balances sheets of budget users are not published, and therefore they are hard to obtain for research purposes;

2. Opinion polls were meant to be filled out by the professionally most capable group (i.e., heads of accounting), so that the risk of unanswered questions due to lack of knowledge was minimized;

3. The prevailing share of questions in the poll was able to be formed as questions of a closed type (i.e., questions), where you could choose one of several offered responses, that shortened the response time and the time of data processing;

4. The opinion poll was carried out as an internet poll from the internet address http://www.kwiksurveys.com, which contributed to the effectiveness of the research performance, there was no limitation regarding the number of questions and the questioned. This approach also provided for an immediate transfer of results into the software tools Excel and SPSS ${ }^{5}$ for the purposes of statistical processing.

5 Data was processed in a version of Office Excel 2003 and in version 17 of the SPSS. 
In the opinion poll the fact that the property balance sheet includes data from the balance sheets of budget users was respected. Therefore, the questions of the poll were directed mainly towards the verification of internal controls providing for accuracy and completeness in the original documents.

Most of the questions were of a closed type, where besides the status "yes" or "no", we also allowed for the response "I don't know." "I don't know" is not a possible status, but information that the accountant does not have any knowledge on the questioned content. If the share of these responses would have been statistically relevant, they would have been validated separately.

Statistically, we handled the responses to the questions as nominal variables, while we established a share of statuses of the handled variable (percentages of the whole). A special case of nominal variables known as dichotomous variables with only two statuses, "yes" or "no", and we can give to them numerical values 1 and 0 for statistical processing.

Only in the part of the component on the risk assessment, we asked for responses on risk validation in accordance with the numerical row from 1 - low to 3 - high, but also these were handled as nominal variables, regarding the share of individual responses.

Due to the specialties in bookkeeping of business events and frequency of their appearance, in the component of controlling activities besides the questions answered by all asked we also formed questions on the existence of tracks for performed controlling activities at characteristic accounts of three groups of budget users taken into the consolidated property balance sheet of the state and municipalities: especially for immediate budget users, special for mediate budget users and especially for public funds and other subjects in the public sector with ownership of property.

We were satisfied with the $90 \%$ claim or with a $10 \%$ risk factor. When we wanted to reach a certain broadness of a planned interval of trust $\Delta p \pm 5 \%$ with $90 \%$ probability or $10 \%$ risk in our population $N=1879$, in the least convenient value the share of responses in the sample $p=50 \%$, the desired sample value $n=238$ was needed. But, due to the circumstances influencing the filling-out of the opinion poll, a great share of unanswered polls was expected. Therefore, we calculated the desired 
Empirical Verification of the Existence and Functioning of Internal

Controls in the Preparation of a Consolidated Property Balance Sheet

for the State and Municipalities in Slovenia

number $\mathrm{n}=238$ increased by a factor of 4 and, due to the simplification of choice, it was rounded down to half of the population, $\mathrm{n}=940$, and the poll was sent to each second address or element from the sample frame.

\subsection{Statistic validation of results of empirical verification of the existence and functioning of internal controls in the process of preparation of a consolidated property balance sheet of the state and the municipalities in the republic of Slovenia}

\subsubsection{Responsiveness of the asked}

In the overview of obtained results, we excluded three responses from the obtained 208 polls, as we assessed them not to be reliable, so we worked on a sample of 205 responses.

The number of responses to the questions or the number of units, as we call all responses by one asked, was lowered according to the series of questions bound to the COSO components. The first group of questions referring to the controlling environment was answered by all respondents, or all 205 asked. In the scope of questions on the risk assessment, 23 responses or $11 \%$ of the reached sample, respectively, were missing. The questions without responses increased to the last group of questions, where 69 respondents or a strong 33\% of the reached sample did not reply.

\subsubsection{Statistic validation of results}

As we received some fewer replies than planned, $n=205$, exactness of results was a little worse than expected in the most inconvenient values of shares of some reply (p) within the sample (n). But, at the same time, the results of the value of shares of individual replies (p) within a sample (n) showed a better picture. As before, the questions were put in a way that a high share of responses of one sort was to be expected (the share of "yes" or "no" of some response to be much higher than $p=50 \%$ ), also intervals of trust were measured more strictly. The broadness of an interval of trust $\Delta p= \pm 5.0 \%$ was reached already at $p=0.7=70 \%$, and became tighter by the increasing of $p$. As in the formula for the standard deviation

$$
\operatorname{se}(p)=\sqrt{ } v(p)=\sqrt{ }\left[(1-f)^{*} p^{*} q /(n-1)\right]
$$


the product $p^{*} q$ and $q=1-p$ appear, also $q$ or $p$, respectively, reach the same deviation, when they are smaller than 50\%. The desired broadness of the interval of trust $\Delta p= \pm 5.0 \%$ was also reached at $p=0.3=30 \%$ and became narrow by a decrease of $p$.

In the opinion poll, in the framework of the component of controlling activities, we addressed certain questions especially to immediate budget users, mediate budget users, and public funds, as we wished to study the standings characteristic for the individual three groups. To the questions to public funds, we obtained only three replies and due to the small number, and so we did not statistically process them. Comparison of broadness of intervals of trust $\Delta p$ for individual groups within the population showed that it has the strongest influence on the exactness of statistical measurement of the size of the sample, as the calculated interval size was twice broader (10\% at immediate users), when the sample is four times smaller ( $\mathrm{n}=57$ at immediate users) in comparison with $\mathrm{n}=205$ at the complete sample with the same $p$.

When the share of units with the followed standing or characteristic is low or when we have smaller samples at our disposal, we have to determine the variation coefficient for the assessment of reliability (Kalton \& Vehovar, 2001, p. 119-128).

In the validation of the results of the polls, we respect the variation coefficient as a measure of reliability of results or the quality of validation of samples. Kalton and Vehovar (2001, p. 127) state that the limit of acceptable relative exactness is set with the value of the variation coefficient $\mathrm{cv}(\mathrm{p})<0.05$. The allowed limit for opinion variables is $c v(p)<0.10$. In higher values of variation coefficients, we have to especially stress the lack of reliability of the results in an eventual publication, but when the variation coefficient exceeds 0.33 , such assessments should not be published.

The vast majority of obtained responses in our opinion poll on controlling systems in the process of preparation of a consolidated property balance sheet of the state and the municipalities reached high shares with the variation coefficient $\mathrm{cv}(\mathrm{p})<0.10$. Besides the responses of public funds within the component of controlling activities that were not tackled due to the minimal size of the sample, also responses to questions put to immediate budget users within this same component were less reliable. 
Empirical Verification of the Existence and Functioning of Internal

Controls in the Preparation of a Consolidated Property Balance Sheet

for the State and Municipalities in Slovenia

\subsection{Results of responses according to COSO components}

For each dichotomy variable and its complementary value (i.e., for each share of responses "yes" and "no" in the sample), we calculated the interval size of the interval of trust $\Delta p$ and the variation coefficient $c v(p)$. We also collected the results of the open type of questions. In them, we wished to find out the opinions of head of accounting on some essential questions or to determine the statistical result on a certain reply through their opinion.

In the contribution, we present the key results for each COSO component.

\subsubsection{Results of responses to questions on the controlling environment}

Existence of internal controls in a controlling environment was verified by 11 complex questions of a closed type. We confirmed that from $49 \%$ to $60 \%$ budget users, or half of them, are of the opinion that the legally set limitation periods for the confirmation of open positions regarding the finalisation of the business year are set too early, using a reliability of $\mathrm{cv}(\mathrm{p})=0.06$ within a $10 \%$ risk. Using the same reliability we confirmed that from $47 \%$ to $58 \%$ budget users are of the opinion that in cases, when the standings of receivables and according liabilities are not confirmed and differ in another budget user, the proceedings are not regulated enough by law. Using a reliability of $\mathrm{cv}(\mathrm{p})=0.03$ with the same risk level, we confirmed that from $83 \%$ to $91 \%$ budget users confirmed short-term receivables and liabilities on 31.12 , despite the fact that legal grounds do not demand such confirmations expressively.

\subsubsection{Results of responses to questions on the risk assessment}

Risk assessments were verified in total by questions of a closed type. We started with general questions on the risk register, and then we verified, whether a subject in the public sector possesses standings on accounts that are consolidated in the property balance sheet.

When the response was affirmative, respondents continued to assess the risk level that the standing of receivables is not equal to the standing of liabilities in another budget user. Using these questions, we wished to obtain information: 
1. On what consolidated accounts most of the budget users state the standing;

2. Which of these accounts, and in what percentage, do they show another risk level for the appearance of differences in the process of consolidation.

With a reliability of $\operatorname{cv}(\mathrm{p})=0.04$ and with a $10 \%$ risk, we confirmed that standings and through them risks that a standing on account 14 short-term receivables towards users of a unified accounting plan will not even exist in the range from $67 \%$ to $77 \%$ of the population. With a reliability of $\mathrm{cv}(\mathrm{p})=0.05$, and within the same risk of the claim, that at a range from $63 \%$ to $73 \%$ of the population have standings and by these risks also have on account 24 - short-term liabilities towards users of a unified accounting plan and in the range from 55\% to $66 \%$ on the account 98 - liabilities towards the assets obtained for management. In spite of this, in each of these affirmative responses, more than $40 \%$ of respondents were of the opinion that the risk of an appearance of differences in consolidation process is low.

\subsubsection{Results of responses to questions on controlling activities}

Controlling activities were checked in the following ways:

1. Using questions of a closed type, respondents were questioned on the identity of registered standings in the bookkeeping registers;

2. Using questions of an open type, we asked the opinion of accountants, why there are mistakes in the consolidation;

3. Using questions of a closed type, we asked three characteristic groups of subjects on the harmonisation of standings within their own bookkeeping registers on different, characteristic consolidated accounts for an individual group.

We asked whether the budget user showed a standing on certain accounts on 31.12, which served as the control question. Using a $10 \%$ risk, with a reliability of $\mathrm{cv}(\mathrm{p})=0.04$, we re-confirmed that the standings of short-term receivables in the population exist in the range from $65 \%$ to $75 \%$, or in two thirds of the budget users, and by the same level of reliability that there are also standings of short-term liabilities, also within two thirds, and this is in the range from $64 \%$ to $74 \%$ of the population. Using a reliability of $\mathrm{cv}(\mathrm{p})=0.07$ and within the same risk, we also confirmed the existence of standings on accounts of certain liabilities for 
assets obtained for management, in the range from $40 \%$ to $50 \%$ of the population.

Using an opinion poll, we then conducted a series of questions of an open type.

Budget users were asked to name the accounts where they did not succeed the consolidated standings by 31.12. They named:

- The general fund for receivables towards assets given to management, the general fund for financial investments, liabilities for assets obtained for management;

- Short-term receivables towards immediate state budget users (dangerous transfers, refunding for care, disability);

- Short-term liabilities towards immediate state budget users;

- Other short-term liabilities from business (liabilities for payments for sickness for more than 30 days);

- Other short-term receivables (receivables towards the Tax Office of the RS);

- Other long-term capital investments in the state;

- Dedicated assets transferred to public funds.

The respondents also named accounts where budget users did not balance the standings with the opposite standings in another budget user at all, in spite of the openness of the positions:

- Short-term liabilities towards the immediate state budget users (all subaccounts, fire protection);

- Short-term receivables towards immediate state budget users (dangerous transfers, refunding for care, disability);

- Other short-term receivables (refunding of disability payments).

The subjects were asked for the naming of causes, due to which the differences in the standings without a net harmonisation with counterstandings appeared. They named the following causes:

- Forms for the confirmation of open positions were not sent to the partners at all or were confirmed in an incorrect way (incorrect naming of ciphers and accounts);

- No regulated division of property between new and old municipality; 
- Budget users do not have registered starting standings of the balance sheets;

- Immediate users for example do not have registered liabilities towards the municipality;

- Immediate users register business events in the past budget period, in spite of the fact that these appeared after 31.12.;

- Frequent use of incorrect accounts;

- Financial statements that were produced too late;

- Documents are not booked, mainly claims, while receivables in another budget user do have a standing;

- On the receivable accounts interest and advance payments are not booked;

- Limitation periods for consolidation are too short.

Then, subjects were asked to name the measures that need to be taken, in their opinion, in order to prevent differences in the consolidation between receivables and liabilities. They proposed the following measures:

- Multiple harmonisations of receivables and liabilities per year, mandatory on 31.10. already, prior harmonisation of standings by telephone;

- Harmonisation of activities bound to the finalisation of the budget year - filing of invoices in time, timely and equally handled budget years, exact registration of business events in the year of appearance of the business event, preparation of a unified instruction for the booking of business events at the end of the budget year;

- Mandatory naming of accounts and ciphers of budget users on forms of confirmation of the standing;

- On documents of budget users included into the property balance sheet a mandatory naming of ciphers of the partners;

- Increased accuracy of work of the responsible persons;

- Clear and concise instructions for the preparation of the property balance sheet.

Differences in the process of consolidation or compensation of standings, due to which a budget user has to increase the source in 
accordance with the standing order on the preparation of the property balance sheet of the state and the municipalities - either the liabilities for assets obtained for management, or a general fund, or a fund of property in public funds, or a fund of property in other subjects in public sector in their ownership - may appear as net difference:

- Of receivables and liabilities of budget users having mutual relations of creditor and debtor;

- Active and passive reservations;

- Unpaid income and unpaid spending.

The subjects were asked whether there was one of these differences appearing in them and if so, whether they had a separately shown lead, for which the source was increased and by how much. By the reliability of $c v(p)=0.07$ and within a $10 \%$ risk, based on the responses, we confirmed that the difference in the compensation in budget users appears in a range from $40 \%$ to $50 \%$ of the population, namely in half of the budget users. By a variation coefficient of $c v(p)=0.10$ and the same interval of trust, we may claim that the existence of a lead on the increase of sources due to differences in the compensation is provided for only by from $26 \%$ to $36 \%$ of the population.

Using questions within the controlling activities addressed to the three most frequent groups of budget users that consolidate data from the balance sheet into a consolidated property balance sheet of the state and the municipalities, we focused our studies on the existence of controls within their own bookkeeping that should provide for a harmonisation between individual accounts and counter-accounts. For a group of public funds, we did not receive enough responses and were not statistically handled. The sample of immediate budget users was only 57 units, and as an average $36 \%$ of the subjects of this group did not answer the questions. Therefore, the variation coefficient is $\operatorname{cv}(p) \geq 0.10$, and the responses are not reliable. Due to more convenient statistical parameters, the responses of mediate budget users are more reliable. These regularly confirm the harmonisation of standings of couple accounts within their own bookkeeping. 


\subsubsection{Results of responses to questions on information and communication}

The questions on information and communication were again meant for all subjects, and the questions were not answered by between 66 units or a 32 percent share of subjects and 68 units or a 33 percent share of subjects. Using a reliability of $\mathrm{cv}(\mathrm{p})=0.09$ within a $10 \%$, risk the results of the opinion poll showed that between $30 \%$ and $41 \%$ share of the population, i.e. one third of the budget users, the software enables the changing of already booked data within the balance sheet, namely the accessing the database. By a reliability of $\mathrm{cv}(\mathrm{p})=0.07$ within the same risk we have confirmed that the leaderships of accounting of budget users between a 39 and 49 percent share of the population of accounting use periodical reports at their decision-making, but they also confirmed by a variation coefficient of $\mathrm{cv}(\mathrm{p})=0.08$ and within the same level of risk that more than one third, between a $33 \%$ and $44 \%$ share of leaderships do not use information from property balance sheets in their decisionmaking. There, within the same level of reliability, the opinion of accountants from the range of a $37 \%$ to $43 \%$ share of the population showed that education opportunities provided by the ministry for accountants of budget users were not frequent enough.

\subsubsection{Results of responses to questions of following}

The component of following was verified by four questions. A total of 60 , or $34 \%$, of the subjects did not answer this series of questions. Using a reliability of $\mathrm{cv}(\mathrm{p})=0.07$ and within a $90 \%$ probability we confirmed that an internal audit of the accounting function was conducted in budget users in the range from $40 \%$ to $51 \%$ of the population, and using the same reliability that in the range of between $39 \%$ and $50 \%$ of the share of the population of budget users, the head of accounting did not ask those preparing the property balance sheets for their eventual problems in the last year. An audit of the process of preparation of the property balance sheet surely was not done by half of the budget users, in the range of between a $47 \%$ and $58 \%$ share of the population, which was confirmed with a reliability of $\mathrm{cv}(\mathrm{p})=0.06$ and within a $10 \%$ risk.

\subsection{Conclusions}

We assumed that differences influencing the bookkeeping standing of the general state fund in the Slovenian consolidated property balance 
Jasna Ida Zafred

Empirical Verification of the Existence and Functioning of Internal

Controls in the Preparation of a Consolidated Property Balance Sheet

for the State and Municipalities in Slovenia

sheet of the state and the municipalities are the consequence of weaknesses in the conducting of the accounting function of public law subjects, which influences the credibility of the data shown in the balance sheet. We tested the assumption by the statistical method of random sampling in the use of an opinion poll in the framework of the COSO components in the process of preparation of a consolidated property balance sheet for the state and the municipalities. For each individual COSO component we applied responses to the pattern of the statistical population of public law subjects with a $90 \%$ probability or a $10 \%$ risk, mainly dichotomous variables, to the whole population and interpreted them in calculations of trust within the measured degree of reliability. The set thesis that consolidated standings was confirmed by our research, in which there was no prior controlling system or where no identical balance positions were discovered and do not provide for a credible consolidated financial statement. We confirmed the existence of quasi-differences in the consolidation process of preparation of a consolidated property balance sheet of the state and the municipalities, and with questions of an open type we found out the reasons of the appearance of quasi-differences and the opinions on the measures of their prevention, as it is seen by the heads of accounting. For the providing of the true and honest consolidated property balance sheet of the state and the municipalities, namely a credibly shown consolidated standing of property on the state level, internal controlling mechanisms will have to be introduced and maintained, mainly in the preparation of original documents of the balance sheet of budget users.

Ms. Jasna lda Zafred, PhD graduated in economics and in law and helds a PhD in Economics. She is certified Auditor, certified Tax Advisor, certified State Auditor and certified State Internal Auditor. She performed tax inspections in different private companies. She was senior State Auditor at the Court of Audit of the Republic of Slovenia, she worked as Head of Internal Audit department at the University of Maribor. Since 2006 she has been working as senior State Internal Auditor in the Ministry of Finance within the Budget Supervision Office of the Republic of Slovenia. She has published over 20 professional articles on accounting and auditing. 


\section{References}

- Allen, T. L., \& Chan, J. L. (2002). Public Accountability and Government Financial Reporting: Models of Public Budgeting and Accounting Reform. OECD Journal on Budgeting 2(1), 12-36.

- Bartov, E. (2003). Discussion of "Investor Sophistication and the Mispricing of Accruals". Review of Accounting Studies 8(2/3), 277-281.

- Beneish, M. D. (1998). Discussion of "Are Accruals during Initial Public Offerings Opportunistic?". Review of Accounting Studies 3(1/2), 209-221.

- Benito, B., Brusca, I. \& Montesinos, V. (2007). The harmonization of government financial information systems: the role of the IPSASs. International Review of Administrative Sciences 73(2), 293-317.

- Bessette Russell, W. (2003). Measuring the Economic Impact of UniversityBased Research. Journal of Technology Transfer 28(3/4), 355-361.

- Broadbent, J. \& Guthrie, J. (2008). Public sector to public services: 20 years of "contextual" accounting research. Accounting, Auditing \& Accountability Journal 21 (2), 129-169.

- Bronstein, I. N., Semediajew, K. A., Musiol, G. \& Mühling, H. (1997). Matematični priročnik. Ljubljana: Tehniška založba Slovenije.

- Fairfield, P. M., Scott, W., Lombardi, T. Y., Whisenant, S. \& Yohn, T. L. (2003). The Differential Persistence of Accruals and Cash Flows for Future Operating Income versus Future Profitability. Review of Accounting Studies 8(2-3), 221-243.

- Hepworth, N. (2002). Government Budgeting and Accounting Reform in the United Kingdom: Models of Public Budgeting and Accounting Reform. OECD Journal on Budgeting 2(1), 116-161.

- Hoque, Z. \& Moll, J. (2001). Public Sector Reform: Implications for Accounting, Accountability and Performance of State-owned Entities: An Australian Perspective. The International Journal of Public Sector Management 14(4), 304-326.

- International Public Sector Accounting Standards Board (2007, februar). IPSAS (2007) Handbook of International Public Sector Accounting Pronouncements. New York: IFAC, International Public Sector Accounting Standards Board (online version). Retrieved 14. 8. 2007, from http://www.ifac.org/Members/Pubs-Details.tmplęPubID= $11726065236097226 \&$ Category=Public\%20Sector\%20Accounting

- International Public Sector Accounting Standards Board (2011, april). IPSAS (2011) Handbook of International Public Sector Accounting Pronouncements. New York: IFAC, International Public Sector Accounting 
Jasna Ida Zafred

\section{Empirical Verification of the Existence and Functioning of Internal Controls in the Preparation of a Consolidated Property Balance Sheet for the State and Municipalities in Slovenia}

Standards Board (online version). Retrieved 29. 7. 2011 , from

http://web.ifac.org/publication

- Jurišič, A. \& Batageli, V. (b.l.). Verietnostni račun in statistika. Retrieved 20. 6. 2010, from http://212.235.189.46/ajurisic/viso8/folije/3x2vs13-14.pdf

- Kalton, G. \& Vehovar, V. (2001). Vzorčenje v anketah. Ljubljana: Fakulteta za družbene vede.

- Kelly, J. \& Wanna, J. (2004). Crashing through with Accrual-Output Price Budgeting in Australia: Technical Adjustment or a New Way of Doing Business? The American Review of Public Administration 34(1), 94-11 1.

- Matheson, A. (2002). Better Public Sestor Governance. The Rationale for Budgeting and Accounting Reform in Western Nations. Models of Public Budgeting and Accounting Reform. OECD Journal on Budgeting 2(1), 3849. Paris: OECD - Organisation for Economic Co-operation and Development.

- Ministrstvo Republike Slovenije za finance (2009, 24. junii). Konsolidirana premoženiska bilanca države in občin na dan 31. 12. 2008. Ljubljana: Ministrstvo za finance. Retrieved 3. 9. 2009, from http://www.mf.gov.si/slov/gl-kni-zakl/konsol_bil_2008.pdf

- Navodilo o pripravi zaključnega računa državnega in občinskega proračuna ter metodologije za pripravo poročila o doseženih ciljih in rezultatih neposrednih in posrednih uporabnikov proračuna. Uradni list RS št. $12 / 2001,10 / 2006$ in 8/2007.

- Pae, J. (2005). Expected Accrual Models: The Impact of Operating Cash Flows and Reversals of Accruals. Review of Quantitative Finance and Accounting 24(1), 5-22.

- Pallot, J. (2002). Government Accounting and Budgeting Reform in New Zealand: Models of Public Budgeting and Accounting Reform. OECD Journal on Budgeting 2(1), 164-186.

- Papenfuß, U. \& Schaefer, C. (2009). Public financial reporting in true and fair terms - discussion on shortfalls in Germany and recommendations for the reform agenda. International Review of Administrative Sciences 75(4), 715-725.

- Pérez, C. C. \& López-Hernández, A. M. (2009). Governmental financial transparency in MERCOSUR member countries. International Review of Administrative Sciences 75(1), 169-181.

- Pravilnik o enotnem kontnem načrtu za proračun, proračunske uporabnike in druge osebe javnega prava. Uradni list RS št. 54/2002, 117/2002, 58/2003, 134/2003, 34/2004, 75/2004, 117/2004, 141/2004, $117 / 2005,138 / 2006,120 / 2007,124 / 2008$ oz. 112/2009.

94 Uprava, letnik IX, 4/2011 
- Pravilnik o določitvi neposrednih in posrednih uporabnikov državnega in občinskih proračunov. Uradni list RS št. 46/2003.

- Pravilnik o pripravi konsolidirane premoženjske bilance države in občin. Uradni list RS št. 26/2003, 117/2005, 120/2007, 32/2008, 10/2009.

- Pravilnik o sestavljanju letnih poročil za proračun, proračunske uporabnike in druge osebe javnega prava. Uradni list RS št. 115/2002, 21/2003, 134/2003, 126/2004, 120/2007, 124/2008.

- Pravilnik o razčlenjevanju in merjenju prihodkov in odhodkov pravnih oseb javnega prava. Uradni list RS št. 134/2003, 34/2004, 13/2005, 138/2006, 120/2007, 112/2009.

- Smernice za standarde notranjega kontroliranja za javni sektor (2005). Ljubljana: Slovenski inštitut za reviziijo.

- Thomas, J. K. \& Zhang, H. (2002). Inventory Changes and Future Returns. Review of Accounting Studies 7(2/3), 163-187.

- Vašiček, V. \& Vašiček, D. (2000). Razvoj Međunarodnih računovodstvenih standarda za javni (proračunski) sektor. Računovodstvo i financije (1 1), 33 43.

- Vrankar, M. (2009). Skupinski računovodski izkazi. Revija IKS XXXVI(1-2), 182-218.

- Wahlen, J. M. (2001). Discussion of: "Do Stock Prices of Property Casualty Insurers Fully Reflect Information About Earnings, Accruals, Cash Flow and Development?" Review of Accounting Studies 6(2/3), 221-228.

- Wilks, S. (2007). Boardization and Corporate Governance in the UK as a Response to Depoliticization and Failing Accountability. Public Policy and Administration 22 (4), 443-460.

- Zafred, J. I. (2010): Prevzem mednarodnih računovodskih standardov za javni sektor v računovodske izkaze oseb javnega prava - primer Slovenije (doktorska disertacija). Ljubliana: Ekonomska fakulteta.

- Zakon o jarnih financah. Uradni list RS št. 79/1999, 124/2000, 79/2001, 30/2002, 56/2002-ZJU, 1 10/2002, 127/2006-ZJZP, 14/2007-ZSPDPO, 109/2008, 49/2009.

- Zakon o računovodstvu. Uradni list RS št. 23/1999, 30/2002, 114/2006. 